\title{
SCHOOL SAFETY AND THE PREVENTION OF DYSFUNCTIONAL BEHAVIORS OF YOUNG PEOPLE IN POLAND - THE CASE STUDY OF SCHOOL STUDENTS FROM THE CITY OF RZESZÓW
}

\begin{abstract}
School safety is the process of creating an appropriate "school climate", which is physically, mentally, emotionally and socially related to a safe space for students and their parents, teachers and the entire school staff. It is connected with the educational and upbringing process, both in typical situations and in the event of potential threats. In order to enable the creation of an appropriate "school climate", it is important to carry out preventive actions in the field of dysfunctional behavior of school youth. The aim of this paper was to present the results of the research conducted in 2020 in Rzeszów on a population of 1091 primary and secondary school students. The results showed that school students were aware that to reduce the scale of dysfunctional phenomena at school, preventive measures should be intensified. Moreover, the youth under the survey had a positive attitude to preventive actions implemented in schools, which translates into an increase in the sense of security at school, the sense of acceptance and appreciation of the student, as well as an increase in awareness of the existence of various social threats.
\end{abstract}

Keywords: safety, schoolchildren, prevention, sociological research.

\section{INTRODUCTION}

All over the world, the issue of school safety has been constantly discussed for nearly 30 years since it is an extremely important topic, but in many countries, including Poland, insufficiently secured on a practical level. The safety of school children in Polish literature

\footnotetext{
${ }^{1}$ Eugeniusz Moczuk, DSc, PhD, Associate Prof., Department of Humanities and Social Studies at the Rzeszow University of Technology; e-mail: e.moczuk@prz.edu.pl (corresponding author). ORCID: 0000-0002-5447-6966.

2 Anna Delekta, PhD, Faculty of Social Sciences, Pedagogical University of Krakow. ORCID: 0000-0002-1480-3029f.

3 Justyna Stecko, PhD, Rzeszów University of Technology, Faculty of Management, Department of Humanities and Social Sciences; e-mail: jstecko@prz.edu.pl.ORCID: 0000-0001-9968-7946.

4 Artur Polakiewicz, M.A., Department of Humanities and Social Studies at the Rzeszow University of Technology; e-mail: polakiewicz@prz.edu.pl. ORCID: 0000-0002-5999-8202.
} 
has been discussed in, among others, Przewłocka (2015), Deptuła (2006) and Łobocki (2004). In foreign literature onecan also find many studies and inspirations, including: O'Moore et al. (2004), Austin, (2003), Bucher et al. (2003), Burns et al. (2001), Daniel et al. (2008). Batanova et al. (2016) or Mori et al. (2021).

Youth as a social category is the subject of analyzes of the sociological sub-discipline of youth sociology (Griese, 1996; Kłoskowska, 1987; Koseła, 1999; Kowalowa et al. 2003; Myszka 2013; Niezgoda, 2014; Pawliczuk, 2006). Therefore, youth is a social category that falls somewhere between childhood and adulthood, in other words, between the category of the "child" and the category of the "adult". The terms "the youth" and "youth" are so capacious that they do not allow an unambiguous analysis of these issues, the more that the concept of youth is used in a somewhat intuitive sense, as opposed to adults (Sokołowska, 2013). It should also be pointed out that adolescents are not only a statistical set, a set of units with similar characteristics, or an age cohort, but also a category of people with similar social characteristics that are important only to them (Niezgoda, 2014).

This approach to the issue results from the fact that each developmental period of a person has its own specific features that are characteristic for a given period of life. When conducting a scientific analysis of the youth and youth, it should be treated in many dimensions, i.e. as a biological, psychological, pedagogical, socio-cultural, economic and legal phenomenon at the same time. In this case, when defining the concept of "the youth" and "youth", science uses various criteria, including: a) biological - as the maturation of the organism, b) psychological - as achieving emotional, intellectual and personality maturity, as well as creating an image of oneself, c) pedagogical - as a course of the education and upbringing process, d) social and cultural - as an element of social maturity and taking on specific social roles, e) economic - as achieving independence in terms of satisfying various material needs, conditioning the start of adult life, f) legal - as achieving the ability to perform specific legal activities (Wysocka, 2010).

It is also important that the youth is a social category very susceptible to the influences of the surrounding reality. On the one hand, it changes the world and introduces its improvements in it, resisting the existing factors, but on the other hand, being very susceptible to the influence of the environment, it allows its free development, different from the development of the generation of their parents or grandparents (Myszka, 2013). ). As Janusz Mariański notes,

the new generation of the Poles, born after the political changes, stopped accepting traditional patterns of life, cared for by generations of their parents and grandparents. Shaping their values and norms, they choose from the "catalog of values" those that are convenient, the best, the least burdensome for them, not bearing any signs of burden, but bringing pleasure, satisfaction of various, sometimes immediate, needs (Mariański, 2009).

Among them there are dysfunctional behaviors, often not perceived by young people as negative, although it should be recognized that such behaviors are characterized by negative associations, being a synonym of something bad, wrongly received, badly associated, negative. As Jerzy Kwaśniewski notes, analyzing the concept of "social pathology", that

the very term of "social pathology" is very unfortunate. The terms-assessments are difficult to avoid in the language of social sciences. However, I think that in order 
to define such a property of human behavior, which consists in their negatively assessed non-compliance with some norms or social expectations, it is better to use, if possible, more emotionally neutral terms, such as, for example, "deviation", "social problems" (Kwaśniewski, 1992).

Thus, it can be seen that the notions of assessment are often treated as topos ${ }^{5}$, largely of an emotional nature, including a negative emotional one. Another important assumption is that such terms as "social pathology", "social deviation", "dysfunctional behavior", "demoralization of minors" and others, i.e. terms assessed as negative, are related to traditional society, where there are clearly defined social norms. as well as sanctions for breaking them. The axionormative level is especially important for young people (Stecko, 2019). However, postmodern society is shaping a completely new quality of phenomena described today as pathological or dysfunctional, but which "tomorrow" may either become "normal" or completely disappear, with the simultaneous formation of new phenomena that are currently still in the futuristic sphere.

However, this analysis does not cover the entire population of youth, whose indicator is age, but school-age adolescents, i.e. people studying in schools, in accordance with the Polish educational system (in this analysis, the research covered students of 7 grades of primary schools and 2 years of post-primary schools). Such an analytical interpretation results not only from the educational needs of young people, but also from the relevant legal provisions. Article 70 (1) 1 of the Polish Constitution states that everyone has the right to education (Behr, 2016). A positive right to education means the obligation to ensure universal and equal access to education, which includes a number of activities, including: a) appropriate shaping of the network of public schools, b) ensuring that parents have the possibility to choose schools other than public schools for their children, c) imposing on the relevant authorities control competences in the field of observing the implementation of the right to education, d) individualization of the teaching process, e) developing the personality and talents of the pupil in the course of education, f) shaping and developing respect for human rights, culture and national identity, g) preparing the child to live responsibly in society and respect human rights (Kozak, 2013).

Therefore, the concept of "school youth" is narrower than the concept of "youth" and a school youth (or in other words "a youth at school age") is a person who has an appropriate level of mental, personality, social and cultural maturity, predisposing them to undertake learning in a specific type of schools suitable for people in a given age category. Thus, the analysis of school youth is based not only on age limits, but also on their physical development, mental level, personality, psychological and social development.

The subject of this study is an attempt to answer the question what the opinions of students of schools in Rzeszów on preventive activities carried out at school are, and the aim of the research is to analyze the effectiveness of preventive activities carried out in schools.

\footnotetext{
5 A topos is a recurring motive, thread, or mental stereotype about a specific social phenomenon. This concept is derived both from literary studies, as well as from mathematics and philosophy (Illusie, 2004).
} 


\section{SCHOOL SAFETY ISSUES AND DYSFUNCTIONAL BEHAVIOR PREVENTION}

An important issue analyzed in this paper is the issue of school safety. School safety is the process of creating an appropriate "school climate", which is physically, mentally, emotionally and socially related to a safe space for students and their parents, teachers and the entire school staff, connected with the educational process, both in typical and upbringing situations and in the event of potential threats (School safety manual Tools for teachers, 2017). The United Nations Sustainable Development Goals also state that schools should provide a safe, non-violent, inclusive and effective learning environment for all ${ }^{6}$.

A safe school is one that provides the individual with broadly understood health, an appropriate level of safety and protection against dangers. It is a school located in a safe local community, having an appropriate "social climate", reacting immediately to any crisis situation (School safety manual Tools for teachers, 2017). According to Amrit Thapa, Jonathan Cohen, Shawn Guffey, Ann Higgins-D'Alessandro, the "social climate" of a school is a system of patterns of school and non-school norms, values and social goals of the school environment, it is interpersonal relation connected with the educational process, it is the school's organizational system, which is created to achieve the goal of a safe educational process. The positive "social climate" of the school contributes to undisturbed physical, emotional, cognitive and social development of students and school staff, as well as influences students' acceptance to undertake learning, better self-development, and improved interpersonal relationships, both inside and outside schools, and thus to create a school safety system free from various threats. Thanks to this, students, their parents, teachers and school staff can cooperate with each other, creating a vision of the school together, developing their relationships that emphasize the benefits of learning (Thapa et al., 2013). Therefore, safe schools have adequate plans to deal with security emergencies, are aware of the risks and monitor red flags, and have adequate reporting systems.

School safety is related to local safety, and local safety is to ensure, by legal means, the functioning of people, residents of a given local community, their protection against crime and other threats that may occur in a given local community (Moczuk, 2009). As can be seen, the local security analytical base is the local community, which is characterized by at least three factors necessary for its existence. They are social interactions, a common area and common ties connecting residents (Odoj, 2007).

Importantly, local communities, based on the actions of local governments (obliged by applicable law), should create a local security system, and thus school safety, implementing appropriate preventive programs aimed at reducing dysfunctional behavior among school children. Therefore, local government should not only realize that it should do "something" for the youngest members of the local community, but should take appropriate actions in this regard. The most important activities in this area include preventive measures in the field of: a) counteracting crimes and misdemeanors in schools and in the immediate vicinity of schools, as well as violence in schools, b) preventing easy access to alcohol and "drugs" in the school environment, c) reacting in situations of inappropriate social reaction to manifestations of dysfunctional and pathological phenomena in the school environment, d) preventing the situation that there is an unsatisfactory level of cooperation between people and institutions responsible for safety in the school environment (especially on the

6 The United Nations General Assembly. Transforming Our World: The 2030 Agenda for Sustainable Development, 2015 [Access: 25.05.2020]. Access on the internet: https://sdgs.un.org/2030agenda. 
line: management - teachers - students - parents - the Police), as well as the possible improvement of interpersonal relations in the school environment, e) counteracting the low level of mutual trust between young people and adults, caused by the lack of identification of existing social problems, fear, reluctance to reliably deal with disturbing phenomena, f) not allowing tolerance of dysfunctional and pathological behaviors, g) conducting all prevention of dysfunctional behaviors with full responsibility (Moczuk et al., 2019).

Therefore, in order the local government could carry out appropriate preventive activities among school youth, it is necessary to: a) systematically monitor the phenomenon of violence at school, drinking alcohol and the use of other psychoactive substances among school youth, b) prepare teachers and other school staff for activities in the field of prevention social problems, c) be more "brave" in their activities to counteract social problems among young people, and prepare legal instruments in the form of resolutions to effectively solve these problems and generate financial resources to conduct preventive activities, d) persons deciding about the activities of the commune cannot be little convinced about the prevention of social problems, and people who directly implement activities in this area in schools should be motivated not only morally, but also organizationally and financially, to make their activities more effective, e) every person who has any contact with young people, in particular teachers, school educators, class educators, should be introduced to the subject of modern forms of interpersonal communication, using technical devices, should master cyberspace using such devices, and also be regular participants of online forums (Moczuk et al., 2019).

Local authorities should not only diagnose social problems of young people, but also take measures to prevent the emergence of social problems among young people, reduce the size of those that currently occur, and increase the resources necessary to deal with existing problems, as well as understand the needs of the local community, but also to conduct effective preventive measures in this regard. Therefore, one cannot disagree with the statement that the social security system enables the satisfaction of various needs of citizens with the help of an efficiently functioning public administration, and the more important the guardian function of the state (in this case also the administration of local self-governments), the higher the level of social security. citizens (Stecko et al., 2015). In the activities undertaken for the benefit of young people, such activities are the most important. Prevention should also be an important element of preventive actions in the local community.

So what is prevention, which should be the subject of activities of local communities? Prevention is a process that supports the development of full health by enabling people to get the help they need to withstand life's difficulties and to achieve a subjectively satisfying, socially constructive and rich life. Within its framework, two streams of activities should be distinguished: a) creating conditions where a person can realize themselves, develop their abilities, seek their own identity, and thus become a physically, mentally, socially and spiritually healthy person, b) eliminate harmful factors for health, such as: poor economic and social conditions, mental stress, the threat of the influence of negative behavior patterns, violence (Graś, 1993). Both these parts are complementary, it is impossible for an individual to be "healthy" when his environment is "sick". Therefore, preventive actions should be part of a social system in which there is positive cooperation between people subjected to the preventive process and those who carry it out.

Conducting preventive actions requires a whole series of actions, ranging from ensuring the best possible conditions for educating young people, through effective therapeutic 
interventions in the event of problems, and ending with controlling risk factors in the environment (Kuberska-Przekwas, 2014). Brunon Hołyst is of the opinion that

most American programs are implemented in schools, and educational projects are aimed at teachers, school educators and psychologists, administration employees, students, parents and volunteers from local communities. (...) It seems particularly important to direct preventive actions towards this community. Civilization, economic, political and social threats increase the number of factors hindering the development of children and adolescents and threatening their mental health (Hołyst, 2002).

Preventive actions should follow a specific scenario. One can then talk about several levels of prevention, among them: a) the first, the most general level covers educational impacts directed at the entire society, in the sphere of attitudes that accept and facilitate problem-solving, b) the second level is influencing a group potentially at risk of demoralization, i.e. diagnostic, c) the third level is institutional and non-institutional influences on demoralized people, $d$ ) the fourth level is helping people who want to stop functioning so far, e) the fifth level is providing help to people, shaping creative attitudes towards life, tendencies to self-realization, the ability to overcome difficulties and return to social activity of the individual (Bałandynowicz, 2014). Each of these levels of prevention (ranging from the most general, to the most specific, individual) is not only important, but also creates a specific system of preventing dysfunctional phenomena, which allows taking action in each of these areas, adequate to a given problem.

Prevention should not only be aimed at putting an end to the further escalation of dysfunctional behaviors, but should aim at assimilating correct forms of behavior by an individual. The essence of the prevention system is to undertake various degrees of interventions preventing the emergence and development of dysfunctional behaviors. In addition, the aim of prevention is to stop the already existing unfavorable development and the initial therapy of disorders leading to unfavorable personality states, and the most important assumption in the implementation of the prevention program is to carry out an accurate diagnosis of the family environment. The school also plays an important role in prevention, and the need for a school to fulfill its preventive function results from the essence and main determinants of contemporary social problems. The school should effectively implement preventive actions among students through a variety of preventive measures, methods and strategies, as well as be a place where the student develops his morale and learns to solve problems. Any symptoms of maladjustment or insufficient adaptation to school conditions should be treated as an extremely important symptom of disturbances in the educational process (Kałdon, 2015).

\section{PREVENTION OF DYSFUNCTIONAL BEHAVIOR AT SCHOOL IN THE OPINION OF STUDENTS OF SCHOOLS IN RZESZÓW}

Assuming that the purpose of this research is to analyze the effectiveness of preventive interventions implemented in schools, in the opinion of primary and secondary school students, the surveys were prepared by means if an electronic questionnaire, carried out using the Survio platform, thanks to which it was possible to reach respondents using electronic carriers, without the need for direct contact between the interviewer and the 
respondents. The research was carried out in September and October 2020, which was related to the existing pandemic state. 1091 primary and secondary school students from Rzeszów participated in the research.

The research question was: does school youth think that conducting preventive activities can reduce the scale of dysfunctional behaviors occurring at school, and what is their assessment. The first hypothesis of the research was: in order to minimize the scale of unfavorable phenomena occurring at school, preventive measures should be intensified among students of all types of schools, and the second hypothesis: school students are positive about social prevention carried out in schools, and such activities must be in schools, intensified due to the increasing scale of dysfunctional behaviors in adolescents (Moczuk, 2020).

$37.9 \%$ of primary school students, $29.8 \%$ of general secondary school students, $31.8 \%$ of technical secondary school students and $0.5 \%$ of basic vocational school students participated in the research. In turn, $36.0 \%$ of the respondents are people up to 14 years old, $7.2 \%-15-16$ years old, 55.9\% - 17-18 years old, and $0.9 \%$ did not provide their age. $50.7 \%$ of girls and $49.3 \%$ of boys participated in the research. The data analysis shows that $8.9 \%$ of respondents declare that their parents have primary education, $14.1 \%$ - basic vocational education, $31.6 \%$ - secondary education, and $45.4 \%$ - higher education (Moczuk, 2020).

The issues related to the analysis of the opinions of primary and secondary school students towards the prevention of dysfunctional behavior are part of the process of creating safety in the school environment, and thus refer to the activities undertaken by local government and local authorities in the field of local security (Moczuk, 2020).

Due to the possibility of various dysfunctional behaviors of minors in the school environment, the school should implement activities in the field of broadly understood prevention. Therefore, the respondents were asked whether they had met with the implemented preventive measures at their school. The distribution of answers to this question is presented in table 1.

Table 1. Implementation of preventive activities by the school in the opinions of respondents

\begin{tabular}{|l|c|c|}
\hline \multicolumn{1}{|c|}{ Specification } & Number & \% \\
\hline Definitely yes & 97 & 8.9 \\
\hline Rather yes & 386 & 35.4 \\
\hline Rather no & 196 & 18.0 \\
\hline Definitely no & 122 & 11.2 \\
\hline Hard to say & 290 & 26.6 \\
\hline Total & $\mathbf{1 0 9 1}$ & $\mathbf{1 0 0 . 0}$ \\
\hline
\end{tabular}

Source: own calculations.

The data presented show that, according to $44.3 \%$ of the surveyed students, preventive measures are implemented (total answers definitely and rather yes), and $29.2 \%$ believe that no (total answers definitely and probably not). As many as $26.6 \%$ of respondents do not have an opinion in this respect. Therefore, it can be concluded that the respondents notice that preventive measures are implemented in their schools, although the fact that one third of the respondents believe that nothing of the sort has happened, and one fourth has no opinion on this, does not allow an unambiguous assessment of such measures. On the one 
hand, it is good that schools implement various preventive programs, but on the other hand, the lack of knowledge results from the fact that such programs do not reach everyone ${ }^{7}$.

Preventive activities undertaken by the school should cover three levels of preventive impact, including universal prevention - addressed to all students, selective prevention addressed to high-risk groups, and indicative prevention - carried out in relation to highrisk students. Each of the levels of action should be adjusted to the degree of risk of dysfunctional behaviors existing in a given school environment (Szymańska, 2012), it is also important that such actions are undertaken as part of a partnership between students, parents and teachers, creating an opportunity for the proper flow of information about problems existing among students (Dubis, 2010). Therefore, students were asked what the most important tasks of the school in the field of prevention should be. The distribution of answers to this question is presented in table 2 .

Table 2. The most important tasks of the school in the field of prevention in the opinion of the respondents $(\mathrm{N}=1091)$

\begin{tabular}{|l|c|c|}
\hline \multicolumn{1}{|c|}{ Specification } & Number & \% \\
\hline Ensuring safety at school and during extracurricular activities & 540 & 49.5 \\
\hline Ensuring safety at school events & 270 & 24.7 \\
\hline Ensuring safety during school trips & 344 & 31.5 \\
\hline Development of mature and responsible student behavior & 564 & 51.7 \\
\hline Teaching how to deal with difficult and crisis situations & 619 & 56.7 \\
\hline Development of physical fitness and sports habits & 330 & 30.2 \\
\hline Raising awareness of the dangers of addiction & 417 & 38.2 \\
\hline Something else & 110 & 10.1 \\
\hline No answer & 51 & 4.7 \\
\hline
\end{tabular}

Source: own calculations.

Due to the fact that the respondents could choose more answers, they do not add up to $100 \%$. On the basis of the data presented, it can be seen that for the respondents prevention is an important element of the educational process, the more so as they indicate that the aim of prevention at school should be to ensure safety at school and during extracurricular

\footnotetext{
${ }^{7}$ To investigate the interdependence between the dependent and independent dependent subscription of measure $\chi^{2}$. For the variable "school type" $\chi^{2}=39.735399$, the number of degrees of freedom $(d f)=12$, significance level $(\alpha)=0.05$, citizenship rights $(p)=7.955 \mathrm{E}-05$, Pearson contingency $\alpha$ control $(C)=0,2129678$ (see: Babbie, 2007), social relations. The strength of the relationship is weak, but it can be indicated that the most often convinced that schools implement various preventive activities are primary and technical secondary school students. For the variable "sex" $\chi^{2}=30.092125, \mathrm{df}=4 . \alpha=0.05, \mathrm{p}=4.688 \mathrm{E}-06, \mathrm{C}=0.2045972$ the relationship is present. The strength of the relationship is weak, but it can be indicated that boys most often indicate that schools carry out various preventive activities. For the variable "age" $\chi^{2}=32.317714$, $\mathrm{df}=8, \alpha=0.05$, $\mathrm{p}=8.169 \mathrm{E}-05, \mathrm{C}=0.1991637$ the relationship exists. The strength of this relationship is weak, but it can be indicated that most often older students indicate that schools implement various preventive measures. For the variable the education of the "head of the family", $\chi^{2}=14.4477576$, $\mathrm{df}=12$, $\alpha=0.05, p=0.27303337, C=0.12987835$ the relationship does not exist. This means that regardless of the education of the "head of the family", students have a similar opinion that schools implement various preventive measures.
} 
activities, as noted by $49.5 \%$ of the surveyed students. On the other hand, $24.6 \%$ of the students pay attention to ensuring safety at school events. $31.5 \%$ of the students talk about ensuring safety during school trips. $51.7 \%$ of the students talk about shaping mature and responsible student behavior. Learning how to cope with difficult and crisis situations is mentioned by $56.7 \%$ of the students. $30.2 \%$ of the students pay attention to the development of physical fitness and sports habits. $38.2 \%$ of the students say that they are aware of the dangers of addiction. And other activities are mentioned by $10.1 \%$ of the students ${ }^{8}$. As one can see, the respondents are of the opinion that the most important task of the school in the field of prevention should be teaching how to deal with difficult and crisis situations, shaping mature and responsible behavior of the individual, as well as ensuring safety at school and during extracurricular activities.

The next question was about the preventive activities organized by the school by the respondents. The distribution of answers to this question is presented in table 3 .

Table 3. Preventive activities organized by the school in which the respondents participated $(\mathrm{N}=1091)$

\begin{tabular}{|l|c|c|}
\hline \multicolumn{1}{|c|}{ Specification } & Number & \% \\
\hline $\begin{array}{l}\text { Programs related to expanding knowledge about addiction to psychoactive } \\
\text { substances }\end{array}$ & 455 & 41.7 \\
\hline $\begin{array}{l}\text { Programs related to the subject of behavioral addictions, including } \\
\text { addiction to gambling, the Internet, computer games, shopping, etc. }\end{array}$ & 276 & 25.3 \\
\hline $\begin{array}{l}\text { Activities allowing to expand the knowledge of recognizing the } \\
\text { manifestations of risky behaviors among young people }\end{array}$ & 210 & 19.2 \\
\hline $\begin{array}{l}\text { Programs that provide up-to-date knowledge of specialist help for people } \\
\text { with alcohol, drug and activity addiction problems }\end{array}$ & 257 & 23.6 \\
\hline $\begin{array}{l}\text { Undertakings to educate people about the risks associated with } \\
\text { adolescence and adolescence as well as risky behaviors }\end{array}$ & 246 & 22.5 \\
\hline $\begin{array}{l}\text { Activities increasing the level of knowledge about the legal consequences } \\
\text { of violating the law in relation to violence at school, drinking alcohol, } \\
\text { using drugs, as well as cyberbullying, including stalking, hacking, } \\
\text { recording and processing of unauthorized content }\end{array}$ & 348 & 31.9 \\
\hline Other activities & 68 & 6.2 \\
\hline None & 346 & 31.7 \\
\hline No answer & 31 & 2.8 \\
\hline
\end{tabular}

Source: own calculations.

Due to the fact that the respondents could choose more answers, they do not add up to $100 \%$. On the basis of the presented data, it can be seen that the respondents participated in a large number of preventive activities carried out by the school. $41.7 \%$ of the respondents participated in the programs related to expanding knowledge about addiction to psychoactive substances. On the other hand, $25.3 \%$ of the respondents participated in programs related to the subject of behavioral addictions, including addiction to gambling,

\footnotetext{
${ }^{8}$ A detailed analysis of the correlation between the dependent and independent variables using the $\chi^{2}$ measure was not performed, because these variables are conjunctive, therefore it is not possible to calculate them.
} 
the Internet, computer games, shopping, etc. $19.2 \%$ of the respondents participated in activities aimed at broadening the knowledge of recognizing symptoms of risky behavior among young people. $23.6 \%$ of the respondents participated in programs providing up-todate knowledge about specialist help for people with alcohol, drug and activity addiction problems. $22.5 \%$ of the respondents participated in projects aimed at raising awareness of the risks associated with adolescence and adolescence as well as risky behaviors. $31.9 \%$ of respondents participated in activities increasing the level of knowledge about the legal consequences of violating the law in relation to violence at school, drinking alcohol, using drugs, as well as cyberbullying, including stalking, hacking, recording and processing of unauthorized content. And $6.2 \%$ of the respondents participated in other activities. As many as $31.7 \%$ of the respondents did not participate in any of them ${ }^{9}$. The fact that as many as one third of the surveyed students did not have the opportunity to participate in any preventive programs is a very negative information, regardless of how students are recruited to such programs.

The respondents were also asked to what extent participation in preventive programs met the needs of respondents related to counteracting addictions and promoting a healthy lifestyle. The distribution of answers to this question is presented in table 4 .

Table 4. Satisfying the needs of respondents related to counteracting addictions and promoting a healthy lifestyle through participation in preventive programs

\begin{tabular}{|l|c|c|}
\hline \multicolumn{1}{|c|}{ Specification } & Number & \% \\
\hline Definitely high & 99 & 9.1 \\
\hline Rather to a good degree & 337 & 30.9 \\
\hline Rather, it does not meet the needs & 181 & 16.6 \\
\hline It doesn't meet my needs at all & 143 & 13.1 \\
\hline Hard to say & 331 & 30.3 \\
\hline Total & $\mathbf{1 0 9 1}$ & $\mathbf{1 0 0 . 0}$ \\
\hline
\end{tabular}

Source: own calculations.

Data analysis shows that, according to $40.0 \%$ of respondents, the needs related to counteracting addictions and promoting a healthy lifestyle are met by participating in preventive programs (total answers to a decidedly and rather high degree), and $29.7 \%$ are of the opposite opinion (total answers definitely and rather not satisfying). As many as $30.3 \%$ of respondents do not have an opinion in this respect. Therefore, it can be concluded that practically a large proportion of the respondents are satisfied with such programs, although a significant number of respondents refraining from responding must have some thought $^{10}$.

\footnotetext{
9 A detailed analysis of the correlation between the dependent and independent variables using the $\chi^{2}$ measure was not performed as these variables are conjunctive, therefore it is not possible to calculate them.

${ }^{10}$ For the variable "type of school" $\chi^{2}=39.044472, \mathrm{df}=12, \alpha=0.05, \mathrm{p}=0.00010347$, $\mathrm{C}=0.21117265$ there is a relationship. The strength of this relationship, calculated using Pearson's contingency coefficient $\mathrm{C}$, indicates that it is weak, nevertheless, it can be indicated that they most often meet the needs related to counteracting addictions and promoting a healthy lifestyle through participation in preventive programs by students of technical secondary schools. For the variable
} 
The issue of school safety related to the preventive activities carried out was the subject of another question, which was whether they feel safe in the school attended by the respondents. The distribution of answers to this question is presented in table 5 .

Table 5. The sense of safety at school in the respondents' opinions

\begin{tabular}{|l|c|c|}
\hline \multicolumn{1}{|c|}{ Specification } & Number & \% \\
\hline Definitely yes & 350 & 32.1 \\
\hline Rather yes & 554 & 50.8 \\
\hline Rather no & 69 & 6.3 \\
\hline Definitely no & 41 & 3.8 \\
\hline Hard to say & 77 & 7.1 \\
\hline Total & $\mathbf{1 0 9 1}$ & $\mathbf{1 0 0 . 0}$ \\
\hline
\end{tabular}

Source: own calculations.

The analysis of the data shows that $82.9 \%$ of the students feel safe at school (in total, the answers definitely and rather yes), and $10.1 \%$ do not feel such safety (total answers definitely and probably not). $7.1 \%$ of respondents do not have an opinion in this respect. Therefore, it can be concluded that the vast majority of respondents feel safe at school, which is very positive information ${ }^{11}$.

The issue of school safety is also related to the issue of positive perception of a given student, acceptance by colleagues, and appreciation by teachers. Therefore, the respondents were asked whether they were accepted and appreciated in the class. The distribution of answers to this question is presented in table 6 .

"sex" $\chi^{2}=26.253787, \mathrm{df}=4, \alpha=0.05, \mathrm{p}=2.813 \mathrm{E}-05, \mathrm{C}=0.1914317$ the relationship exists. The strength of this relationship is weak, and therefore girls more often than others meet the needs related to counteracting addiction and promoting a healthy lifestyle through participation in preventive programs. For the variable "age" $\chi^{2}=32.856292, \mathrm{df}=8, \alpha=0.05, \mathrm{p}=6.537 \mathrm{E}-05$, $\mathrm{C}=0.200778$ the relationship exists. The strength of this relationship is weak, so older students more often than others meet the needs related to counteracting addiction and promoting a healthy lifestyle through participation in preventive programs. For the variable the education of the "head of the family", $\chi^{2}=36.8429173, \mathrm{df}=12, \alpha=0.05, \mathrm{p}=0.00023689, \mathrm{C}=0.20533281$ there is a relationship. The strength of this relationship is weak, and therefore students whose parents have secondary and higher education more often than others meet the needs related to counteracting addictions and promoting a healthy lifestyle through participation in preventive programs.

${ }^{11}$ For the variable "type of school" $\chi^{2}=38.03221, \mathrm{df}=12, \alpha=0.05, \mathrm{p}=0.00015171, \mathrm{C}=0.20851066$ there is a relationship. The strength of this relationship is weak, and therefore students of general and technical secondary schools have a higher sense of security in school related to the preventive activities. For the variable "sex" $\chi^{2}=25.426028, \mathrm{df}=4, \alpha=0.05, \mathrm{p}=4.13 \mathrm{E}-05, \mathrm{C}=0.1884595$ there is a relationship. The strength of this relationship is weak, and therefore boys have a higher sense of security in school related to the preventive activities. For the variable "age" $\chi^{2}=15.826392, \mathrm{df}=8, \alpha=0.05, \mathrm{p}=0.0449335, \mathrm{C}=0.1404175$ the relationship exists. The strength of this relationship is weak, and therefore people aged 14-16 have a significant sense of security in school related to the preventive activities carried out. For the variable the education of the "head of the family", $\chi^{2}=6.75109024, \mathrm{df}=12, \alpha=0.05, \mathrm{p}=0.87361466, \mathrm{C}=0.0890924$ the relationship does not exist. This means that regardless of the education of the "head of the family", everyone has a similar sense of security at school related to the preventive activities carried out. 
Table 6. Sense of acceptance and appreciation of the respondent in the class

\begin{tabular}{|l|c|c|}
\hline \multicolumn{1}{|c|}{ Specification } & Number & \% \\
\hline Definitely a high sense of acceptance & 310 & 28.4 \\
\hline Rather high sense of acceptance & 542 & 49.7 \\
\hline Rather low sense of acceptance & 77 & 7.1 \\
\hline Definitely low sense of acceptance & 38 & 3.5 \\
\hline Hard to say & 124 & 11.4 \\
\hline Total & $\mathbf{1 0 9 1}$ & $\mathbf{1 0 0 . 0}$ \\
\hline
\end{tabular}

Source: own calculations.

The presented data show that $78.1 \%$ of the students have a high sense of acceptance and appreciation of the respondent in the class (total answers definitely and rather yes), and $10.6 \%$ are of the opposite opinion (total answers definitely and probably not). $11.4 \%$ of respondents do not have an opinion in this respect. Therefore, it can be concluded that over three-fourths of the respondents feel accepted and appreciated in their class ${ }^{12}$.

At the end of the research, the respondents were asked whether they are aware of the dangers of risky behaviors of young people. The distribution of answers is presented in table 7 .

Table 7. The respondents' awareness of the dangers resulting from risky behaviors of young people

\begin{tabular}{|l|c|c|}
\hline \multicolumn{1}{|c|}{ Specification } & Number & \% \\
\hline Definitely yes & 473 & 43.4 \\
\hline Rather yes & 456 & 41.8 \\
\hline Rather no & 69 & 6.3 \\
\hline Definitely no & 40 & 3.7 \\
\hline Hard to say & 53 & 4.9 \\
\hline Total & $\mathbf{1 0 9 1}$ & $\mathbf{1 0 0 . 0}$ \\
\hline
\end{tabular}

Source: own calculations.

${ }^{12}$ For the variable "type of school" $\chi^{2}=22.501068$, df $=12, \alpha=0.05, p=0.03227303$, $\mathrm{C}=0.16149605$ there is a relationship. The strength of this relationship is weak, and therefore most often a high sense of acceptance and appreciation in the classroom is experienced by technical students. For the variable "sex" $\chi^{2}=24.518817, \mathrm{df}=4, \alpha=0.05, \mathrm{p}=6.285 \mathrm{E}-05, \mathrm{C}=0.1851421$ the relationship exists. The strength of this relationship is weak, so boys more often than girls have a high sense of acceptance and self-esteem in the classroom. For the variable "age" $\chi^{2}=21.672427$, $\mathrm{df}=8, \alpha=0.05, \mathrm{p}=0.0055602, \mathrm{C}=0.1638815$ the relationship exists. The strength of this relationship is weak, and therefore most often people aged 17-18 have a high sense of acceptance and self-esteem in the class. For the variable the education of the "head of the family", $\chi^{2}=34.3747857, \mathrm{df}=12, \alpha=0.05, \mathrm{p}=0.00058857, \mathrm{C}=0.19955328$ there is a relationship. The strength of this relationship is weak, and therefore students whose parents have higher and secondary education more often than others have a high sense of acceptance and self-esteem in the classroom. 
The presented data show that $85.2 \%$ of the students are aware of the threats resulting from risky behaviors of young people (total answers: definitely and rather yes), and $10.0 \%$ do not have such awareness (total answers: definitely and probably not). $4.9 \%$ of respondents do not have an opinion in this respect. Therfore, it can be concluded that the vast majority of respondents are aware of the threats that "lurk" for young people ${ }^{13}$.

In order to summarize these considerations, it should be noted that school students are aware of the fact that minimizing the scale of unfavorable phenomena occurring at school, including dysfunctional behavior, is related to the intensification of preventive activities carried out among students of all types of schools, regardless of age, and such preventive measures increase the sense of security at school, the sense of acceptance and self-esteem of the student, as well as the increased awareness of various social risks in the internal and external environment of the school. The research also shows that schoolchildren have a positive attitude to preventive actions implemented in schools, although not all preventive measures are actively involved. However, they express their readiness to conduct prevention in schools due to the increasing scale of dysfunctional behaviors of young people.

\section{CONCLUSIONS}

It should be noted that the aim of the research, which was to analyze the effectiveness of preventive measures implemented in schools, was achieved and the hypotheses were verified.

The first hypothesis, which was: in order to minimize the scale of unfavorable phenomena occurring at school, preventive measures should be intensified among students of all types of schools, was verified positively as the examined school youth is aware of the fact that minimizing the scale of adverse phenomena occurring at school, including dysfunctional behaviors, is associated with the intensification of preventive activities carried out among students of all types of schools, regardless of age, because such preventive activities increase the sense of security at school, the sense of acceptance and self-appreciation of the student, as well as an increase in awareness of the existence of various social risks in the internal and external environment of the school. On the other hand, the second hypothesis, which was: school youth has a positive attitude to social prevention implemented in schools, and such activities must be intensified in schools due to the increasing scale of dysfunctional behaviors of young people, was partially confirmed as research shows that the respondents have a positive attitude to preventive actions implemented in schools, but not all preventive measures take an active part. However, they

\footnotetext{
${ }^{13}$ For the variable "type of school" $\chi^{2}=20.822918$, df $=12, \alpha=0.05, p=0.05303445$, $\mathrm{C}=0.15547431$ the relationship does not exist. Regardless of the type of school, all students are equally aware of the dangers of risky behaviors of young people. For the variable "sex" $\chi^{2}=34.283606, \mathrm{df}=4, \alpha=0.05, \mathrm{p}=6.518 \mathrm{E}-07, \mathrm{C}=0.2179747$ there is a relationship. The strength of this relationship is weak, and therefore girls are more often than boys aware of the dangers of risky behaviors in adolescents. For the variable "age" $\chi^{2}=15.368305$, df $=8, \alpha=0.05$, $\mathrm{p}=0.0523674, \mathrm{C}=0.1383994$ the relationship does not exist. Regardless of age, all students are equally aware of the dangers of risky behaviors of young people. For the variable the education of the "head of the family", $\chi^{2}=20.8227341, \mathrm{df}=12, \alpha=0.05, \mathrm{p}=0.05303727, \mathrm{C}=0.15547364$ the relationship does not exist. Regardless of the education of the "head of the family", all students are equally aware of the dangers of risky behaviors of young people.
} 
express their readiness to conduct prevention in schools due to the increasing scale of dysfunctional behaviors of young people.

Therefore, the following measures should be proposed in the field of preventive measures in schools:

1. Prepare teachers and school staff for activities in the field of prevention of dysfunctional behaviors. It should be related to the social integration of people and institutions dealing with social problems, which should lead to increasing knowledge about these problems and understanding the essence of the problems.

2. The local government should be more 'brave' in its actions to counteract dysfunctional behaviors among young people, and prepare legal instruments in the form of resolutions to effectively solve such problems and generate financial resources to conduct preventive actions.

3. Decision-makers must be convinced that the prevention of dysfunctional behavior is the most effective way to achieve the goal of a safe school.

4. A kind of prevention of dysfunctional behaviors should be public debates on social problems of school youth, with the participation of representatives of local authorities, the Police, school principals and teachers, school youth and their parents.

\section{REFERENCES}

Austin, V.L. (2003). Fear and loathing in the classroom: A candid look at school violence and the policies and practices that address it. „Journal of Disability Policy Studies”, Vol. 14, No. 1.

Babbie, E. (2007). Badania społeczne w praktyce. Warszawa: Wydawnictwo Naukowe PWN.

Bałandynowicz, A. (2014). Profilaktyka i prewencja zachowań suicydalnych $w$ okresie adolescencji u dzieci i młodzieży. ,,Resocjalizacja Polska”, nr 6.

Batanova, M., Loukas, A. (2016). Empathy and Effortful Control Effects on Early Adolescents' Aggression: When Do Students' Perceptions of Their School Climate Matter? „, Appl. Dev. Sci. ", 20.

Behr, J. (2016). Prawo do nauki w podmiotach leczniczych. Analiza na przykładzie publicznej szkoły podstawowej specjalnej. ,,Folia Iuridica Universitatis Wratislaviensis”, Vol. 5(2).

Bucher, K.Y., Manning, M.L. (2003). Challenges and suggestions for safe schools. „The Clearing House”, Vol. 76, No. 3.

Burns, M.K., Dean, V.J., Jacob-Timm, S. (2001). Assessment of violence potential among school children: Beyond profiling. ,, Psychology in the Schools”, Vol. 38, No. 3.

Daniel, Y., Bondy, K. (2008). Safe schools and zero tolerance: Policy, program and practice in Ontario. ,Canadian Journal of Educational Administration and Policy”, Vol. 70.

Deptuła, M. (2006). Diagnostyka i profilaktyka w teorii i praktyce pedagogicznej. Bydgoszcz: Wydawnictwo Uniwersytetu Kazimierza Wielkiego.

Dubis M. (2010). Wspótpraca szkoły z policja w zakresie profilaktyki zachowań agresywnych u młodzieży. „Ius et Administratio”. Zeszyt specjalny, „III Forum Socjologów Prawa. Prawo i ład społeczny, Facultas Iuridica Universitatis Ressoviensis, Rzeszów.

Gaś, Z. B. (1993). Rodzina wobec uzależnień. Warszawa: Wydawnictwo PARPA.

Griese, H. M. (1996). Socjologiczne teorie młodzieży. Kraków: Oficyna Wydawnicza Impuls.

Hołyst, B. (2002). Suicydologia. Warszawa: Wydawnictwo Prawnicze LexisNexis. 
Illusie L., What is... a Topos?, Notices of the American Mathematical Society 2004, vol. 51, nr 9, s. 1060-1061.

Kałdon B. M., Przestępczość wśród nieletnich a podejmowane działania profilaktyczne, Seminare 2015, nr 3, tom 36, s. 117-128.

Kłoskowska A., Socjologia młodzieży. Przegląd koncepcji, Kultura i Społeczeństwo 1987, nr 2, s. $19-37$.

Koseła, K. (1999), Młodzież [w:] Kwaśniewicz, W., red., Encyklopedia socjologii, t. 2. Warszawa: Oficyna Wydawnicza.

Kowalowa, A. I., Łukow, W. A. (2003). Socjologia młodzieży. Szczecin: Wydawnictwo Wyższej Szkoły Humanistycznej Towarzystwa Wiedzy Powszechnej w Szczecinie.

Kozak, M. (2013). Prawo dziecka do edukacji. Założenia pedagogiczno-prawne i bariery realizacyjne. Warszawa: Biuro Rzecznika Praw Dziecka.

Kuberska-Przekwas, K. (2014). Samobójstwa dzieci i młodzieży jako choroba społeczna. „,Warmińsko-Mazurski Kwartalnik Naukowy, Nauki Społeczne”, nr 1.

Kwaśniewski, J. (1992). Ontologiczny status patologii społecznej [w:] Kojder, A., Kwaśniewski, J., red., Między autonomia a kontrola. Warszawa: Wydawnictwo Uniwersytetu Warszawskiego.

Łobocki, M. (2004). Wybrane problemy wychowania. Lublin: Wydawnictwo Uniwersytetu Marii Curie-Skłodowskiej.

Mariański, J., Dylematy moralne młodzieży polskiej [w:] Walczak-Duraj, D., red., Wartości i postawy młodzieży polskiej. Łódź: Wydawnictwo Uniwersytetu Łódzkiego.

Moczuk, E., Bajda, K. (2016). Problemy i zjawiska patologiczne w społeczeństwie tradycyjnym i nowoczesnym. Studium socjologiczno-kryminologiczne. Rzeszów: Wydawnictwo Uniwersytetu Rzeszowskiego.

Moczuk, E., Leśniak-Moczuk, A. D. (2019). Działania samorząu terytorialnego i Policji w sferze bezpieczeństwa lokalnego wobec młodzieży szkolnej [w:] Surma, A., Śliwa, M., red., Wybrane zagadnienia z zakresu nauk spolecznych i mediów. Lublin: Wydawnictwo Naukowe TYGIEL.

Moczuk, E. (2009). Socjologiczne aspekty bezpieczeństwa lokalnego, Rzeszów: Wydawnictwo Uniwersytetu Rzeszowskiego.

(2020). Młodzież Miasta Rzeszowa wobec problematyki przemocy w szkole, używania środków psychoaktywnych $i$ uzależnień behawioralnych. Rzeszów: Urząd Miasta Rzeszowa, Fundacja Rozwoju i Wsparcia „Pasieka”, Politechnika Rzeszowska.

Mori, Y., Tiiri, E., Khanal, P., Khakurel, J., Mishina, K., Sourander, A. (2021). Feeling Unsafe at School and Associated Mental Health Difficulties among Children and Adolescents: A Systematic Review. „Children”, 8(3). DOI: 10.3390/children8030232.

Myszka, L. (2013)., Autoidentyfikacje wspótczesnej młodzieży - przyczynek do dyskusji na temat: Młodzież, czyli kto?. „Kultura-Społeczeństwo-Edukacja”, nr 2(4).

Niezgoda, M. (2014). Młodzież. Kłopotliwa kategoria socjologiczna. „Jagiellońskie Studia Socjologiczne", nr 1.

O’Moore, M., Minton, S.J. (2004). Dealing with Bullying in Schools. A Training Manual for Teachers, Parents and Other Professionals. Wydawnictwo: SAGE Publications Ltd.

Odoj, G. (2007). Tożsamość kulturowa społeczności małomiasteczkowej. Katowice: Wydawnictwo Uniwersytetu Śląskiego.

Pawliczuk, W. (2006), Definicje terminu „młodzież”-przegląd koncepcji. „Postepy Nauk Medycznych", nr 6. 
Przewłocka, J. (2015). Raport przygotowany w ramach projektu systemowego Badanie jakości i efektywności edukacji oraz instytucjonalizacja zaplecza badawczego. Warszawa. Access on the internet: http://produkty.ibe.edu.pl/docs/raporty/IBE-raport-przemoc-klimat-wszkole.pdf

School safety manual Tools for teachers (2017). UNESCO-IICBA Published, Addis Ababa.

Sokołowska, A. (2013). Prawa autorskie a młodzież akademicka. Konteksty prawne i spoteczno-pedagogiczne. ,Kultura - Społeczeństwo - Edukacja”, nr 2(4).

Stecko, J. (2019). Applied ethics, i.e. the issue of norms and values in the choices of everyday life. „Logos i Ethos”, t. 49, z. 1.

Stecko, J., Karnasiewicz, E. (2015). Zagrożenie bezpieczeństwa społecznego w ocenie ludzi młodych. „Zeszyty Naukowe Wyższej Szkoły Informatyki, Zarzadzania i Administracji $w$ Warszawie”, nr 3(32), t. 13.

Szymańska, J. (2012). Zapobieganie samobójstwom dzieci i młodzieży. Poradnik dla pracowników szkół i placówek oświatowych oraz rodziców. Warszawa: Wydawca Ośrodek Rozwoju Edukacji.

Thapa, A., Cohen, J., Guffey, S., Higgins-D’Alessandro, A. (2013). A Review of School Climate Research. "Review of Educational Research", Vol. 83, No. 3.

Wysocka, E. (2010). Doświadczanie życia w młodości - problemy, kryzysy i strategie ich rozwiązywania. Próba opisu strukturalno-funkcjonalnego modelu życia preferowanego przez młodziė z perspektywy pedagogiki społecznej, Katowice: Wydawnictwo Uniwersytetu Śląskiego.

DOI: $10.7862 /$ rz.2021.hss.35

The text was submitted to the editorial office: September 2021.

The text was accepted for publication: December 2021. 